\title{
Service quality and consumer satisfaction in food-beverage establishments: Kastamonu case study
}

\author{
Aydoğan Aydoğduํㄹ Emrah Yaşarsoy², Tuğba Dilsiz ${ }^{3}$
}

\begin{abstract}
Eating and drinking is one of the most basic requirements that people need to survive. Recent conditions sometimes do not allow people to cook at home. Intensive work pressure and stress cause people to eat out more. At this point, individuals prefer places where service quality and satisfaction are high. The aim of this study was to measure the satisfaction of the consumers as a result of the quality of service offered in the food and beverage establishments in Kastamonu. A correlational survey method was used in this study. Consumers who have visited food-beverage establishments in Kastamonu constituted the universe of the study. The research sample consisted of 400 customers-determined by multilevel sampling method-who visited the food and beverage establishments in Kastamonu and Daday District. Face to face and drop-collect questionnaire techniques were implemented in the research. The data were analysed by a statistical package program which is widely used for social sciences. Exploratory Factor Analysis was conducted with Principal Component Analysis. Findings have revealed that the respondents' views created 3 dimensions and named as Functional Quality, Technical Quality and Image Quality.
\end{abstract}

Keywords: Food \& Beverage Establishments, Service Quality, Consumer Satisfaction, Kastamonu

\section{Yiyecek içecek işletmelerinde hizmet kalitesi ve tüketici doyumu: Kastamonu örneği}

\begin{abstract}
$\ddot{O} z$
Insanoğlunun hayatta kalabilmek için ihtiyaç duyduğu en temel gereksinimlerden biri yeme-içmedir. Günün şartları insanların evde yemek yapmalarına bazen olanak tanımamaktadır. Yoğun iş temposu ve stres insanların daha çok dlşarıda yemek yemelerine neden olmaktadır. Bu noktada bireyler hizmet kalitesinin ve tatmininin yüksek olduğu yerleri tercih etmektedirler. Bu çalışmanın amacı, Kastamonu'da bulunan yiyecek-içecek işletmelerinde sunulan ürün ve hizmetin kalitesine koşut tüketicilerin doyumunu ölçmektir. Çalışmada, İlişkisel Tarama Modeli işe koşulmuştur. Araştırmanın evrenini Kastamonu'da bulunan yiyecek-içecek işletmelerini tercih eden tüketiciler oluşturmuştur. Araştırma örneklemi ise Kastamonu ve Daday Illçesindeki yiyecek-içecek işletmelerini ziyaret eden çok düzeyli örnekleme yöntemine göre belirlenmiş 400 müşteridir. Çalışmada yüz yüze ve bırak-topla anket teknikleri uygulanmıştır. Sonuçlar sosyal bilimlerde sıkça kullanılan bir istatistik paket programıyla çözümlenmiștir. Temel Bileşenler Analizi ile Keşfedici Faktör Analizi yapılmıştır. Bulgular, katılımcıların görüşlerinin 3 boyut oluşturduğunu ve bu boyutların Işslevsel Kalite, Teknik Kalite ve İmaj Kalitesi olarak adlandırıldığını ortaya koymuştur.
\end{abstract}

Anahtar sözcükler: Yeme \& İ̧̧me Iş̧letmeleri, Hizmet Kalitesi, Tüketici Doyumu, Kastamonu.

Geliş Tarihi $\quad: 27.09 .2018$

Alıntı için: Aydoğdu, A., Yaşarsoy, E., Dilsiz, T. (2019). Yiyecek içecek işletmelerinde hizmet kalitesi ve tüketici doyumu: Kastamonu örneği. Journal of Tourism Theory and Research, 5(2), 155-170.

\footnotetext{
${ }^{1}$ Dr. Öğr. Üyesi, Kastamonu Üniversitesi, Turizm Fakültesi

${ }^{2}$ Sorumlu yazar, Araş. Gör., Kastamonu Üniversitesi, Turizm Fakültesi, emrahyasarsoy@hotmail.com

${ }^{3}$ Kastamonu Üniversitesi, Sosyal Bilimler Enstitüsü
} 


\section{Giriş}

Fransız Devrimi (Tanilli, 2002) ve bu tarihsel olay1 izleyen y1llarda buhar gücünün endüstride kullanılmaya başlanmasıyla (Köktaş ve Gölçek, 2016) birlikte Avrupa'da sosyo-kültürel ve politik anlamda önemli değişimler yaşanmış, bu değişimler ekonomik yaşamı da derinden etkilemiştir. Endüstri Devrimi ile birlikte artan üretim beraberinde yeni yönetim felsefelerinin gelişmesine de yol açmıştır. Günümüzde Çağdaş Yönetim Guruları olarak tanımlanan Henri Fayol, Frederick Winslow Taylor (Özer, 2015) ve Max Weber gibi düşün insanlarının yapmış oldukları katkılar ile olağanüstü miktarlarda kaydedilen verimlilik artışları beraberinde ücretlerde iyileşme, çalışma saatlerinin azalması ve ücretli tatil olgularının da ortaya çıkması sonucunu doğurmuştur.

Endüstri alanında kaydedilen tüm bu gelişmeler işgücü profilinde de önemli bir değişime yol açmış ve kadınlar hemen hemen her alanda erkeklerle yarışır hale gelmişlerdir (International Labor Organization [ILO], 2018; Kaya, 2009). Kadının işgücüne daha fazla katılımı toplumsal rollerin yanı sıra toplum yaşamında da köklü değişikliklerin olması sonucunu doğurmuştur. İş yaşamında daha aktif roller almaya başlayan kadın, günü birlik yaşamdaki eş ve/ya anne rollerinden ise aynı ölçüde uzaklaşma olanağına hiçbir zaman sahip olamamıştır (Balaban ve Özdemir, 2013). Bir başka ifadeyle kadın hem geleneksel eş ve anne rollerini yüklenirken, bunun üzerine bir de iş kadını rolünü yüklenmiştir (Başöz, 2017).

Sosyal, kültürel, ekonomik ve politik gelişmelerin yol açtığı sayısız değişimlerden bir diğeri de ev dışı tüketim olgusudur. Çünkü ekonomik yaşamda daha çok yer almaya başlayan kadının günden güne artan iş yükü nedeniyle evde yemek hazırlamaya zaman ve güç bulamaması, dışarında yemek yeme olgusunu ön plana çıkarmaktadır (Süren ve Küçükkömürler, 2018; Robson vd., 2016; Arıker, 2012). Araştırmalar ev dış1 tüketim olgusunun günden güne güçlenerek gelişeceğini ortaya koymaktadır (Majabadi vd., 2016; Robson vd., 2016; Özdemir, 2010; Orfanos vd., 2007). Kar1 koca çalışan çiftlerin ekonomik olarak çok zorlanmadan destekleyebildikleri bu eğilim büyük-küçük hemen hemen tüm yerleşkelerde yeme içme olanağ sunan işletmelerin çeşitlenerek yaygınlaşmasını da beraberinde getirmiştir (Crawford, 2016; Denizer, 2005). Tüm bu gelişmelerin doğal bir sonucu olarak günümüz toplumlarl, büyük boyutlara ulaşmış olan Yiyecek Iç̧ecek Hizmetleri Endüstri sinin ürettiği ürün ve hizmetleri giderek artan oranlarda tüketmektedirler. Bu eğilim, çağdaş tüketicilerin dışarıda yemek yeme davranışlarının bir sonucudur. Dışarıda yemek yeme olgusu, temelde ev dişı yiyecek içecek tüketimi ile ilgilidir. Ticari anlamda ise dışarıda yemek yeme, bireylerin ev dışında bir işletme tarafindan üretilen ve servis edilen yiyecek ve içecekleri ücret ödeyerek tüketmelerini ifade etmektedir (Liu vd., 2016; Özdemir, 2010; Guthrie vd., 2002). Nitekim günümüzde Dünya ölçeğinde ev dış1 tüketimin ulaşmış olduğu büyüklük yaklaşık 825 Milyar Amerikan Doları (\$) olup, 2023 yılına dek yıllık ortalama \% 4 ila 5 oranında büyüyerek 1 Trilyon \$'a ulaşması beklenmektedir (Rewardsnetwork, 2017). Bu olgunun Türkiye'deki 2017 yılı değerinin ise y1llık yaklaşık 18,5 Milyar \$ (65 Milyar TL) civarında olduğu ifade edilmektedir (Brandday, 2018; Hotelrestoranmagazin, 2018). Bu büyüklükleri sağlayan restoran sayıları ise 2018 y1lı itibarıyla Amerika Birleşik Devletleri (ABD)'nde 660.775 (The Statistics Portal [STATISTA], 2019a), Avrupa'da ise 2015 y1lı sonu itibaryyla 930.300'a ulaşmıştır (STATISTA, 2019b). Ülkemizde ise günümüz itibarıyla yeme içme alanında etkinlik gösteren işyeri sayısı hakkında güvenilir bir istatistiğe rastlanılmamıştır. Bununla birlikte, bu sayının onbinlere ulaşmış olduğu tahmin edilmektedir.

Yiyecek içecek işletmelerinin çeşitlenerek yaygınlaşması, bu alanda da çetin bir rekabetin doğması sonucunu beraberinde getirmiştir (Chen vd., 2018; Bucak ve Turan, 2016; Olcay ve Özekici, 2015; De Silva vd., 2013). Günümüz Dünyası'nda her endüstride olduğu gibi Yiyecek İ̧ecek Hizmetleri Endüstrisi'nde de rekabet üst noktalara taşınmıştır. Bu yüksek rekabet ortamında işletmeler mevcut müşterilerini rakip firmalara kaptırmamanın yanı sıra yenilerini de eklemek amacıyla büyük bir çaba harcamaktadırlar. Bu yüzden, son zamanlarda hizmet kalitesinin olası faydaları üzerine yapılan araştırmalara odaklanılmıştır. Böylesi bir ekonomik çevrede, üretilen ürünlerde önemli ölçüde farklılaşma sağlanamadığ 1 için genel anlamda tüm endüstrilerde ön planda tutulmaya başlanan hizmet kalitesi Yiyecek İçecek Hizmetleri Endüstrisi için de hayati bir öneme sahip olmaya başlamıştır. Özellikle de insan ilişkilerinin yoğun olduğu yiyecek içecek işletmele- 
rinde, hizmet kalitesinin belirli bir ölçüde olması, o işletmenin rakip işletmelerden daha önde yer almasını sağlamaktadır (Koçbek, 2005). Zira, ilgili yazında kaliteli bir hizmetin müşteri doyumuna, doyumun da sadakate yol açtığı hususunda geniş bir uzlaşı vardır (Filiz ve Kolukısaoğlu, 2013; Kuzu, 2010; Yuen ve Chan, 2010; Ming ve Sheih, 2006; Zhao vd., 2002; Tütüncü, 2001; Zeithaml vd., 1996).

Bir ürün ve/veya hizmetin işlevi, o işletmeyi tercih eden veya edebilecek müşterilerin istem ve gereksinimlerine yanıt vermesidir. Başka bir ifadeyle ürün ve/veya hizmetler insan gereksinimlerini karşılayan araçlar olarak tanımlanabilir. Herhangi bir ürün ve/veya hizmetin belirli bir kaliteye sahip olması, onun tüketiciyi ne ölçüde doyuma ulaştırdığı ile doğru orant1lıdır (Grönroos, 1990; Parasuraman vd., 1990; Uyguç, 1998).

Yiyecek İ̧ecek Hizmetleri Endüstri'nde hizmet sunan işletmeler müşterilerin gereksinimlerine yanıt verebilmek, onları memnun edebilmek ve kaliteli hizmet ortaya koyabilmek için gerek teknolojik, gerekse de sosyal anlamda yaşanan gelişmeleri yakından takip etmek durumundadırlar. İşletmenin sunmuş olduğu hizmetin belirli bir kalitede olması öncelikle müşterileri ve buna bağlı olarak o işletmenin başarısı için son derece önemli bir hale gelmiştir. Tüketicilerin hizmet kalitesi beklentisi, konuya yönelik ilgiyi de arttırmıştır. Çünkü müşteriye sunulan hizmetin kalitesinin yüksek olması, müşteriyi yeniden o işletmeden ürün ve/veya hizmet almaya yöneltmektedir (Kumar ve Bhatnagar, 2017; Oh, 1999). Bir hizmet işletmesinin başarısı, o işletmenin sadık müşteri sayısını arttırma ve hizmet yeterliliğini sürdürebilmesi ile ölçülmektedir. Bundan dolayı, hizmetler sektöründe kalite anlayışının tam anlamıyla yerleşmesi ve kalite standartlarının belirlenmesi, hizmet kalitesi bileşenleri ve kalitenin arttırılması ihtiyacını doğurmaktadır (Ayaz ve Yalı, 2017; Crosby vd., 1990).

Hizmet kalitesine olan ilginin bir diğer doğal sonucu ise sunulan hizmetlerin kalitesinin ölçülmesi zorunluluğudur. Çünkü hizmetlerin tüketici ya da müşterilerin beklentilerini ne ölçüde karşıladığı ortaya konmadan başarımın saptanmasına olanak yoktur. Ayrıca, müşteri ya da tüketicilerin almış oldukları hizmetin kalitesinin ölçülmesi soyut bir süreç sonucunda ortaya çıkmakta olup işletmelerin sürekliliği açısından izlenmesi gereken bir husustur (Oğlakcıŏlu, 2013; Kuzu,
2010; Ersöz vd., 2009; Y1lmaz, 2007; Cronin vd., 2000; Parasuraman vd., 1994; Parasuraman vd., 1991).

Anlatılanlar 1şı̆̆ında, araştırmanın amacı Kastamonu'da etkinlik gösteren yeme içme işletmelerinin sunmuş oldukları ürün ve hizmetlere yönelik tüketici doyumunun ölçülmesi ve bu doyuma yol açan boyutların ortaya konmasıdır. Bu bağlamda araştırmada aşağıdaki soruların yanıtları aranmaktadır:

* Kastamonu'da bulunan yiyecek ve içecek işletmelerinin hizmet kalitesi nedir?

* Kastamonu'daki yiyecek ve içecek işletmelerine gelen tüketicilerin doyumu ne düzeydedir?

* Tüketici doyumuna etki eden faktörler nelerdir?

Çalışma, ilgili yazında birikmiş bilgiye dayandırılan gerekçeli bir sorun sunumunun yer aldığ 1 "Giriş" bölümü; hizmet kalitesi, hizmet kalitesinin boyutları ve hizmet kalitesinin ölçülmesi konularının ele alındığı ve bu alanda yapılmış çalışmaların yer aldığ "Kuramsal Çerçeve ve Illgili Çalışmalar" bölümü; araştırmada yanıtı aranan sorulara geçerli ve güvenilir yanıtlar bulabilmek için ortaya konan araştırma tasarımının genel hatlarıyla anlatıldığı "Yöntem" bölümü; elde edilen sonuçların ortaya konduğu "Bulgular" bölümü ve son olarak araştırma sonuçlarının irdelendiği "Tartışma, Sonuç ve Öneriler" bölümlerinden oluşmaktadır.

Araştırma sonuçlarının birçok yönden yarar sağlayacağına inanılmaktadır. Zira Kastamonu kalkınmada öncelikli iller arasında olmasına rağmen bu sancılı sürecin henüz başındadır. Kara ulaşımının yetersizliği, İnebolu Limanı'nın gümrüğe sahip gelişmiş bir limana dönüştürülememesi, demiryolu ulaşımının olmaması ve coğrafi yapının elverişsizliği gibi etmenler Kastamonu'nun gelişimini engellemiştir (Aydoğdu vd., 2015). Bu gerçekliğe karşın son yıllarda Kastamonu'da sosyo-ekonomik olduğu kadar kültürel, politik ve çevresel anlamda da geri kalmışlığı turizm ile aşma konusunda büyük bir kamuoyu ve uzlaşı oluşmuş bulunmaktadır (Aydoğdu ve Duman, 2017; Arslan, 2015; Babaş, 2014). Anılan sorunların genelde turizm, özelde ise Gastronomi Turizmi ile aşılabileceği hususundaki genel inancın bir hayal kırıklığına dönüşmemesi için yiyecek içecek hizmetleri sunan işletmelerle ilgili tüketici doyumunun önemli olduğu ve ölçülmesi gerektiğine inanılmaktadır. Ayrıca Kastamonu'da böylesi 
bir bilimsel çalışmanın henüz yapılmamış olması nedeniyle ilgili yazında var olduğu düşünülen eksiğgin de bir ölçüde giderileceği ifade edilebilir.

\section{Kuramsal çerçeve ve ilgili çalışmalar}

\subsection{Kalite kavramı}

Hammurabi Yasaları'ndaki bilgilerden (King, 2105; İpekgil-Doğan ve Tütüncü, 2003) varlığından haberdar olduğumuz "kalite" olgusunun aslında insanlık tarihi kadar eski olduğu ifade edilmektedir (Juran, 1995). Kalite, Latince nasıl oluştuğu anlamına gelen "qualis" sözcüğünden türetilmiştir (Anderson ve De Saussure, 2018).

Çok farklı biçimlerde tanımlanabilen kalitenin günümüz yazınındaki en güçlü karşılıkları Juran'ın “ $k u l$ lanıma uygunluk (Sandholm ve Kondo, 1999)" ve Crosby'nin "şartlara uygunluk (Fox, 2013)" tanımlamalarıdır. Amerikan Kalite Derneği (American Society for Quality [ASQ])'nin tanımına göre kalite; "bir mal ya da hizmetin belirli bir gerekliliği karşllayabilme yeteneklerini ortaya koyan karakteristiklerin tümüdür" (ASQ, 2019).

Kalite tanımındaki bu çeşitliliğin temelinde, tanımlanmasındaki zorluk ve kalite değerlendirmelerinin bireyden bireye değişen doğası gelmektedir kuşkusuz. Ancak söz konusu hizmetler olduğunda, kalite tanımlaması daha da karmaşık bir hal almakta ve somut mallarla ilişkili ürünlere göre farklılaşmaktadır. $\mathrm{Bu}$ nedenle, hizmet kalitesi olgusunun ayrı bir alt başlıkta ele alınmasında yarar görülmektedir.

\subsection{Hizmet kalitesi}

Çok genel bir tanımlamayla "üretildiği yerde tüketilen bir iş, eylem, bir performans, sosyal olay veya çaba olarak tanımlanan "hizmet" (Collier, 1990) günümüz çağdaş ekonomilerinin odaklandığı bir üründür. Hizmet denen olgunun bu kadar odakta olmasina yol açan en önemli unsur ülke ekonomilerini oluşturan sektörler arasında almış olduğu büyük paydır. Nitekim günümüz gelişmiş ekonomilerinin $\% 70$ 'den fazlası hizmetler sektöründe etkinlik gösteren işletmelerden oluşmakta olup, Amerika Birleşik Devletleri (ABD)'nde bu oran \%75 civarındadır (Buckley ve Majimdar, 2018).

Hizmetleri önemli k1lan tek unsur ekonomiler içerisindeki oranı değildir kuşkusuz. Zira, hizmet ürünü so- mut nitelik taşıyan mallardan ayrılmakta ve kalite değerlendirmeleri açısından da ayrı bir önem taşımaktadır. Bu farklılığın temelinde yatan en belirgin olgu ise hizmetlerin somut mallardan ayrilan özellikleridir. Bunlar çoğu kaynakta soyutluk, ayrılmazlık, çabuk bozulurluk ve değişkenlik olarak dörtlü bir sınıflamayla açıklanır iken, bazı kaynaklarda sahipsizlik de eklenmekte ve beş özellikle karakterize edilmektedir (Dalgıç, 2013; Ekmekçi ve Ekmekçi, 2010; Lennon, 2008; İpekgil-Doğan ve Tütüncü, 2003; Uyguç, 1998; Zeithaml vd., 1985). Say1lan tüm bu nitelikler hizmet kalitesinin belirlenmesini zorlaştırmakta ve konuya yönelik hatırı sayılır bir yazının oluşması sonucunu da doğurmuş bulunmaktadır.

\subsubsection{Hizmet kalitesinin ölçülmesi}

Hizmetlerin karakteristik özellikleri hizmet kalitesinin ölçülmesi, kontrolü ve yönetimi ile ilgili çalışmaların fiziksel mal üreten işletmelerde olduğundan farklı bir yaklaşımla incelenmesini zorunlu kılmaktadır (Uyguç, 1998). Bu nedenle, ilgili yazında hizmet kalitesi ölçümü ile ilişkili birçok modelin geliştirildiği görülmektedir (Aytar vd., 2018; Aksu ve Memiş, 2017; Songur vd., 2017; Tuncer, 2017; Rao ve Sahu, 2013; Apte vd., 1994; Collier, 1990; Grönroos, 1990). Bunlardan ilki Grönroos tarafindan 1982 yılında geliştirilen ve Nordic Model olarak da bilinen hizmet kalitesi modelidir (Ghotbabadi vd., 2015). Bu modeli Parasuraman ve arkadaşlarının geliştirmiş olduğu SERVQUAL modeli izlemiştir (Parasurman vd., 1995). SERVQUAL modeli aynı zamanda Cronin ve Taylor tarafindan geliştirilmiş olan SERVPERF modelinin (Cronin ve Taylor, 1992) yanı sira Stevens ve arkadaşları tarafindan geliştirilmiş olan DINEPERF modeline (Stevens vd., 1995) de temel teşkil etmiştir.

Bunların dışında da hizmet kalitesini ölçen birçok model geliştirilmiştir. Bunlardan bazıları DINESCAPE, LODGQUAL, ECOSERVE (Tuncer, 2017; Mensah, 2009), Toplam Kalite Endeksi, Kritik Olaylar Yöntemi, Hizmet Barometresi, İstatistiksel Yöntemler ve Diğer Yöntemler olarak sıralanmaktadır (Eleren, 2009).

$\mathrm{Bu}$ çalışmada ilgili yazında en çok öne çıkan modellere yer verilecek olup Parasuraman ve arkadaşları tarafından geliştirilen SERVQUAL modeli, Cronin ve Taylor tarafindan geliştirilen SERVPERF modeli ve 
SERVQUAL modelinin Stevens ve arkadaşları tarafindan yeme içme işletmelerine uyarlanmasıyla elde edilen DINESERV modeli ele alınacaktır.

\subsubsection{SERVQUAL modeli}

SERVQUAL hizmet kalitesinin ölçülmesi amaciyla ilk kez kullanılan modeldir. Bu nedenle üzerinde en çok tartışılan ve belki de ilgili yazında en çok sözü edilen modeldir. Modelin geliştirilmesinde Parasuraman ve arkadaşlarının hizmet kalitesinin müşterilerin herhangi bir hizmeti kullanmaya yönelten etmenleri bir dizi bilimsel çalışma ile saptadıkları boyutlar belirleyici olmuştur. Araştırmacılar hizmet kalitesini tanımlamaya ve onu etkileyen faktörleri (boyutları) bulmaya ve daha sonra da ölçülebilir hale getirebilmek için her hizmet türüne uygulanabilecek genel bir model geliştirmeye çalışmışlardır (Bozdağ vd., 2003'den aktaranlar Halis vd., 2010).

Parasuraman ve arkadaşları hizmet kalitesinin tan1mını yapabilmek için hedef kitle üzerinde müşteri beklenti ve algiları arasındaki farkın tespitinde öncelikle hizmetin 10 genel boyutunu belirlemișlerdir. Belirlenen bu boyutlar; "fiziki/somut özellikler, güvenilirlik, heveslilik, yeterlik, nezaket, inanllırlık, güvenlik/emniyet, elverişlilik, iletişim ve tüketiciyi anlama" olarak s1ralanmaktadır. 1988 yılındaki çalışmalarında 97 ifade ve 10 boyuttan oluşan nicel çalışmalarını dört farklı hizmet sektöründe (bankacılık, telefon işletmeleri, kredi kartları ve ürün tamir ve bakım hizmetlerinde) aşamalı olarak uygulamışlar ve süreçte bazı ifade ve boyutları birleştirmişlerdir. Çalışmalarının sonucunda tüm eleştirilere rağmen ve en çok kullanılan 22 ifade ve 5 boyuttan oluşan SERVQUAL ölçeğini oluşturmuşlardır (Eleren, 2009). Bu boyutlar (Halis vd., 2010; Eleren, 2009; Parasuraman vd., 1985):

- Somut/Fiziksel Özellikler (Tangibles): İşletmenin hizmet sunumundaki bina, araç-gereç ve personel görünümü,

- Güvenirlilik (Reliability): Söz verilen bir hizmeti doğru ve güvenilir bir şekilde yerine getirebilme yeteneği,

- Heveslilik (Responsiveness): Müşteriye yardım etme ve hızlı hizmet verme istekliliği,

- Güven (Assurance): Çalışanların bilgili ve nazik olmaları ve müşterilere güven duygusu uyandırabilmeleri becerisi,
- Empati (Emphaty): İşletmenin kendisini müşterilerin yerine koyarak bireysel dikkat ve müşterilere kişisel ilgi göstermesi biçiminde sıralanmıştır.

Hizmetler soyut nitelikte oldukları için, hizmet kalitesi de soyut bir doğaya sahiptir. Bu nedenle "hizmet kalitesi" yerine "algllanan hizmet kalitesi" betimlemesi kullanılmaktadır (Uyguç, 1998). Algılanan hizmet kalitesi ise müşterinin hizmeti almadan önceki beklentileri ile yararlanma sonrası edinmiş olduğu hizmet deneyimini (alg1lanan hizmeti ya da performans1) kıyaslamasının bir sonucu olup, müşterilerin beklentileri ile algılanan performans arasındaki farkın yönü ve derecesi olarak değerlendirilmektedir (Rao ve Sahu, 2013; Mensah, 2009; Tavmergen, 2002; Tütüncü, 2001; Apte vd., 1994). Hizmet kalitesi ile ilgili yazında "beklenti" sözcüğü ile vurgulanan ise müşterilerin hizmete ilişkin istem ya da arzularıdır (Lewis ve Booms, 1983; Grönroos, 1983; Lehtinen, 1983; Parasuraman vd., 1985, 88; Zeithaml vd., 1985, Sasser vd., 1978; Norman, 1988'den aktaran Uyguç, 1998).

Şekil 1. Algılanan hizmet kalitesi modeli

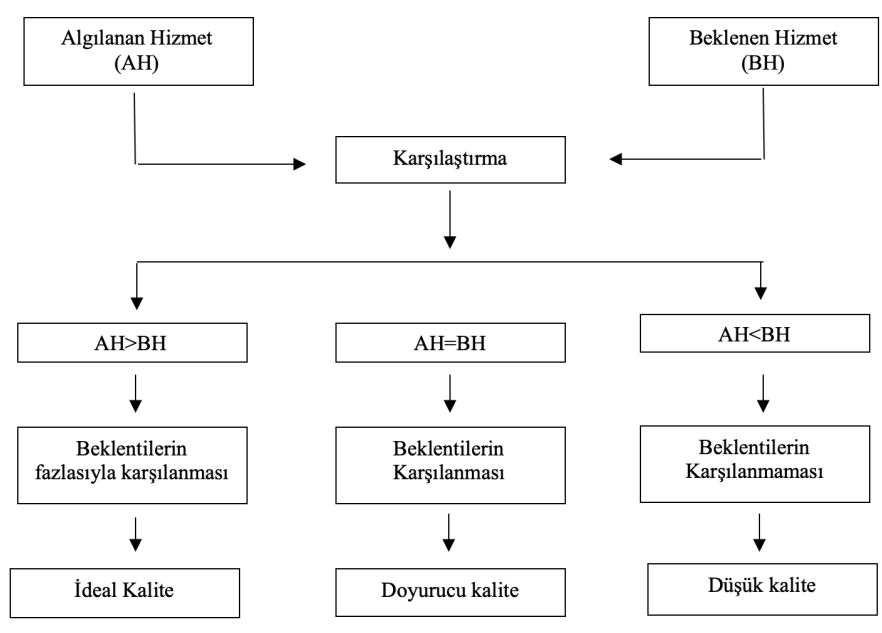

Kaynak: Uyguç, 1998; 29

\subsubsection{SERVPERF modeli}

Hatırlanacağ gibi SERVQUAL modeli müşterilerin hizmet kalitesi beklentileri ve algıları arasındaki skorların farkından hizmet kalitesinin ölçülmesine dayanmakta idi. Hizmet kalitesinin ölçümünde önemli bir diğer model ise SERVPERF modelidir (Songur vd., 2017). Cronin ve Taylor tarafindan 1992 yılında yazına kazandırılan bu model SERVQUAL modelinden farkl1 olarak yalnızca hizmet performansı üzerine odaklanmış ve müşteri algısı yoluyla hizmet kalitesinin ölçül- 
mesini hedeflemiştir. Araştırmacılar hizmet kalitesi ölçümü için iki ayrı değerlendirme yapılmasının gereksiz olduğunu ifade etmişler (Cronin ve Taylor, 1992) ve SERVQUAL modelinde hizmet kullanımı öncesi beklentilerin ölçülmesi yerine doğrudan algıların ölçülmesinin daha sağl1klı sonuçlar vereceğini ileri sürmüşlerdir.

\subsubsection{DINEPERF modeli}

SERVQUAL modelinin bazı kısitlarının olması, araştırmacıların daha kolay uygulanabilir modeller üzerinde yoğunlaşmaları sonucunu doğurmuştur (Marković vd., 2013). Bu çabaların öncelikle ilgili yazının derinlemesine taranmasinı gerektirmesi mevcut modellerin birkaç küçük değişiklik ya da farklı bakış açılarıyla türevlerinin de üretilmesini beraberinde getirmiştir. DINESERV modeli de bu türden bir çabanın sonucunda ortaya çıkmıştır. SERVQUAL modeli Stevens ve arkadaşları (1995) tarafindan restoran müşterilerine uygulanabilecek hale getirilmiştir. İlk uyarlamasinda restoran müşterilerinin algıladıkları hizmet kalitesini ölçmeye yönelik 40 ifadenin yer aldığı model, sonraki aşamada 29 ifadeyle hizmet kalitesini ölçecek biçimde değiştirilmiştir.

Stevens ve arkadaşlarının geliştirmiş olduğu DINEPERF modelinin SERVQUAL'e göre en belirgin fark1, güvenirliğin en önemli boyut olarak ilk sırada yer almasıdır. Güvenirliği sırasıyla fiziksel özellikler, güven, heveslilik ve empati izlemiştir (Marković vd., 2010).

\section{3. İlgili çalışmalar}

Yiyecek içecek işletmelerinde sunulan hizmet kalitesi ilgili yazın tarandığında hem uluslararası hem de ulusal düzeyde çok sayıda araştırmanın yapıldığ 1 görülmektedir.

Marković ve arkadaşları (2013) Zagreb şehrindeki restoranlardaki hizmet kalitesini ölçmek istemişler ve DINEPERF modelini işe koştukları bir alan araştırması yürütmüşlerdir. Araştırmacılar çalışmalarında üç sorunun yanıtını aramışlardır. Bunlar: Müşterilerin Zagreb şehrindeki restoranlardan hizmet kalitesi beklentileri nedir? Müşterilerin Zagreb şehrindeki restoranlardaki hizmet kalitesi algıları nedir? Beklenen ve algılanan kalite arasındaki farklar nelerdir? biçiminde sıralanmıştır (Marković vd., 2013).

Yeme içme işletmelerinde sunulan hizmet kalitesi ile ilgili bir diğer çalışma Mensah (2009) tarafindan
Cape Coast şehrinde yapılmıştır. Özgün (orijinal) SERVQUAL ölçeğinin kullanıldığı araştırmada katılımcıların anılan şehrin restoranlarında sunulan hizmet kalitesi algıları ölçülmek istenmiş̧ir (Mensah, 2009).

Tran (2018) gelecek kariyer hedefi olarak belirlediği restoran işletmeciliği için birinci elden bilgi edinmek amacıyla yapmış olduğu tez çalışmasında, Helsinki şehrindeki restoranlarda sunulan hizmet kalitesini ve müşteri memnuniyetini araştırmıştır. Tran, araştırmasında; "Mevcut restoran müşterilerinin ne kadar memnun oldukları" ve "Restorana gitme kararlarında ve memnuniyetlerinde etkili olan faktörlerin ortaya konması" olarak tanımladığı iki sorunun yanıtlarını aramıştır. Araştırmacı, belirlemiş olduğu sorulara geçerli ve güvenilir yanıtlar bulabilmek amaciyla 32 ifadeli bir ölçek hazırlamış ve Facebook ortamında verileri toplamıştır (Tran, 2018).

Bilgin ve Kethüda (2017) yürütmüş oldukları araştırmada Bartın'da etkinlik gösteren bir restoran müşterilerinin hizmet kalitesi algılarının memnuniyet ve sadakate etkisini incelemişlerdir. Araştırmacılar, çalışmalarında veri toplama aracı olarak DINESERV ölçeğini kullanmışlardır (Bilgin ve Kethüda, 2017).

Bucak ve Turan (2015) Çanakkale il merkezinde bulunan 1 . ve 2 . sinıf restoran işletmelerinde yiyecek içecek hizmet kalite algısının, müşterilerin demografik özelliklerine göre farklılık gösterip göstermediğini araştırma konusu olarak seçmişlerdir. Araştırmacılar 430 bireyin katılımını sağladıkları çalışmada veri toplama aracı olarak Parasuraman ve arkadaşları tarafindan geliştirilen SERVQUAL ölçeğini kullanmışlardır (Bucak ve Turan, 2015).

Bekar ve Kılıç (2015), Muğla Sitkı Koçman Üniversitesi yerleşkesi içerisinde hizmet veren yeme içme işletmelerinde sunulan hizmetlerle ilgili tüketici memnuniyetini karşılaştırmalı bir biçimde ortaya koymak istemişlerdir. Araştırmacılar ilgili yazını tarayarak oluşturmuş oldukları 30 ifadeli ölçeği veri toplama aracı olarak kullanmışlardır (Bekar ve Kılıç, 2015).

\section{Yöntem}

$\mathrm{Bu}$ bölümde araştırmanın kapsamı, tasarım türü, kaynağı, nüfusu (tanımlanmış evren ya da anakütle), örneklemi, modeli ve yöntemi, veri toplama tekniği ve aracı, araştırmanın süresi, analiz yöntemi, güvenirlik ve geçerlik konularına yer verilmiştir. 
Bu çalışma, Kastamonu'da bulunan yiyecek içecek işletmelerinde tüketim yapan müşterilerin almış oldukları ürün ve hizmet kalitesinin yanı sıra doyumlarını ölçme amacıyla gerçekleştirilmiştir. Çalışmada, Kastamonu'da bulunan yiyecek içecek işletmelerinde sunulan ürün ve hizmetin kalitesi ve sunulan ürün ve hizmetlerden tüketicilerin elde ettikleri doyum araştırma konusu olarak seçilmiştir.

\subsection{Araştırmanın kapsamı}

Araştırma birbiri ile ilişkili iki sorunu çözmek için tasarlanmıştır. Öncelikle Kastamonu'da bulunan yiyecek içecek işletmelerinin sunduğu ürün ve hizmet kalitesi, sonrasında ise tüketicilerin duymuş oldukları doyum ölçülmek istenmiş olup bu doyumu oluşturan değişkenlerin neler oldukları araştırmanın kapsamını oluşturmaktadır.

\subsection{Araştırmanın modeli ve tasarımı}

Araştırmanın kapsam ve amacına ve bunlara koşut belirlenmiş olan araştırma sorularına geçerli ve güvenilir cevaplar sağlayacak yöntem "Tarama"dır. Bu sebeple araştırmada "Tarama Modeli" işe koşulmuştur. Tarama Modelleri geçmişte ya da halen var olan bir durumu olduğu gibi betimlemeyi amaçlayan araştırma yaklaşımlarıdır. Modelde araştırmaya konu olay, birey ya da nesne kendi koşulları içinde olduğu gibi tanımlanmaya çalışılır. Onları herhangi bir şekilde değiştirme ve/ya etkileme çabası gösterilmez. Başka bir deyişle, var olan durum olduğu gibi ortaya konur (Karasar, 1984). Tarama Modeli'nde bilimin gözleme, kaydetme, olaylar arasındaki ilişkileri saptama, kontrol edilen değişmez ilişkiler üzerinde genellemelere varma amaçları vardır. Bir başka ifadeyle, bilimin tasvir işlevi ön plandadır (Yıldırım, 1966).

Anlatılanlar 1şığında, araştırmada işe koşulan modelin bir "Illişkisel Tarama Modeli" olduğunu söylemek olanaklıdır. Bu modelle araştırma sorularına geçerli ve güvenilir çözümler bulabilmek amacıyla öncelikle ilgili yazın derinlemesine taranmış ve elde edilen ikincil verilerin yardımıyla bir ölçek geliştirilmiştir. Geliştirilen ölçek (anket) kolayda ve gönüllülük yaklaşımlarıyla belirlenmiş katılımcılara yüz-yüze görüşmelerin yanı sıra bırak topla yaklaşımlarıyla uygulanmıştır.

Araştırmada ortaya konmak istenenleri sağlayacak durum, görüş ve tutumları saptamak amacıyla gelişti- rilen ölçek iki bölümden oluşturulmuştur. Birinci bölüm, katılımcıların Kastamonu'da bulunan yiyecek içecek işletmelerinden aldıkları hizmetten (kalitesinden) duymuş oldukları doyum ya da doyumsuzluk sonucu genel memnuniyetlerini veya memnuniyetsizliklerini ölçmektedir. İkinci bölümde ise katılımcıların profillerini ortaya koymaya yönelik demografik sorulara yer verilmiştir. Bu sorular temel olarak isimsel ve sıralama ölçekleri ile hazırlanmış soru ifadelerinden oluşmuştur.

\subsection{Araştırmanın kaynağı, nüfusu, örneklemi}

Kastamonu'da bulunan yiyecek içecek işletmelerini tercih eden tüketiciler araştırmada görüşüne başvurulan katılımcıların kaynağını oluşturmuştur. Hemen her bir bireyin yılın belirli gün ve saatlerinde ev dışında tüketimde bulunduğu günümüz çağdaş kent yaşamında, araştırmanın anakütlesini (evrenini) oluşturması gereken sayının tespitine olanak olmadığını düşünülmektedir. Bununla birlikte, araştırma örneklemi olarak Kastamonu ve Daday ilçesindeki yiyecek içecek işletmelerini tercih eden gönüllülük esasına göre belirlenmiş 400 kişinin 1.000 .000 kişilik bir anakütleyi temsile yeterli olduğu (Krejcie \& Morgan, 1970) söylenebilir. Araştırma örneklemine Daday'ın dâhil edilmesinin temel nedeni anılan ilçenin özellikle hafta sonları hatırı sayılır sayıda yeme içme tutkunu bireyi ilçeye çekmesidir.

\subsection{Araştırmanın sinırlılıkları}

Çalışma örnekleminde yalnızca 18 yaşından büyük yetişkin ve Türkçe konuşan bireylere yer verilmiştir. Ev dışı tüketimde çocuklar önemli bir kesimi temsil etmelerine rağmen araştırma dışında tutulmuşlardır.

\subsection{Araştırmanın veri toplama aracı ve tekniği}

Çalışmada veri toplama aracı olarak anket formları kullanılmıştır. Anket formunun geliştirilmesinde öncelikle ilgili yazın taranmış ve elde edilen bilgiler 1ş1ğında bir ölçek geliştirilmiştir. Hizmet, hizmet kalitesi, konaklama işletmelerinde hizmet kalitesi, yiyecek-içecek işletmelerinde müşteri doyumunun ölçülmesi, konaklama işletmelerinde müşteri doyumunun ölçülmesi ve hizmet yönetimi konularında yayınlanmış kitap, makale ve araştırmalar incelenmiştir. Bu inceleme sonucunda "müşteri doyumunun" ya "kaliteli mal ve/veya hizmet ile özdeş" kabul edildiği, ya da "kaliteli mal ya da hizmet sunumunun bir işlevi olduğu" saptan- 
mıştır. Ancak son yıllarda hizmet kalitesi araştırmacıları, beklentilerin önemini kabul etmekle birlikte daha farklı bir uygulamayı yeğlemektedirler. Bu uygulama yöntem zorlukları ve kısıtlar nedeniyle beklenti ve performansın ayrı ayrı ölçülmesi yerine hizmet sonrası değerlendirmelerin analizidir (Duman ve Öztürk, 2005). Oliver (1997) daha geniş anlamıyla müşteri memnuniyetini "bir mal ve hizmetin bir özelliğinden veya bütün olarak kendisinden, tüketimle ilgili keyif verici doyum yargısı" olarak tanımlamaktadır (Duman 2003). Araştırmada kullanılan doyum ölçeği yukarıda vurgulanan inceleme ve görüşlere koşut, Kastamonu'da etkinlik gösteren yeme içme işletmelerinde hizmet alan müşterilerin tüketim sonrası memnuniyet durumlarını ölçme esasına dayandırılmıştır.

Anket formunun birinci bölümünde katılımcıların Kastamonu'da bulunan yiyecek içecek işletmelerinden almış oldukları ürün ve hizmetlerin kalitesi ile ilgili doyumlarını ölçmek amaciyla oluşturulmuş on beş adet bağımsız değișken (ifade) yer almıștır. Bu ifadeler kesinlikle kat1liyorum $=5$, kesinlikle katılmıyorum $=1$, biçiminde beşli Likert Tipi ölçeğe göre hazırlanmıştır.

Anket çalışması, tüketicilerin tercih ettiği yiyecek işletmelerinde yargısal biçimde belirlenmiş bir yaklaşımla gönüllülük esasının temel alındığı bir teknikle yüz-yüze görüşmeler biçiminde yürütülmüştür. Ayrıca, yiyecek içecek işletmelerinin yönetimlerinden izin alınarak anket formlarının bırak-topla yöntemiyle de doldurulmalarına olanak sağlanmıştır.

\subsection{Araştırmanın analiz yöntemi}

Çalışma sürecinde anket tekniği ile elde edilen veriler niteliklerine göre çözümlenmiştir. Katılımcıların demografik bilgilerini elde etmeye yönelik hazırlanmış olan kategorik değişkenler sıklık ve yüzdelerle, doyum belirlemeye yönelik beșli Likert tipi ölçeğe göre hazırlanmış bağımsız değişkenlerin yer aldığı ifadeler ise Faktör Analizi ile çözümlenmiştir.

Faktör Analizi, birbiriyle ilişkili çok sayıda değişkeni bir araya getirerek anlamlı az sayıda yeni değişkenler (faktörler veya boyutlar) bulmayı, keşfetmeyi amaçlayan çok değişkenli bir istatistik olarak tanımlanabilir (Büyüköztürk, 2002). Açıklayıcı (keşifsel) ve doğrulayıcı olmak üzere iki farklı biçimde yapılabilen faktör analizi bu çalışmada işe koşulan ölçeğin araştırmacılar tarafından geliştirilmiş olması nedeniyle açıklayıcı (keşifsel) olarak uygulanmıştır (Alpar, 2017). Faktör Analizi ile katılımcıların Kastamonu'da bulunan yiyecek içecek işletmelerinde sunulan ürün ve hizmet kalitesi kaynaklı doyumları daha az sayıda değişken ile ortaya konmuştur. Bu analiz çerçevesinde ayrıca güvenirlik düzeyi için Cronbach's Alfa hesaplamas1 yapılmıştır. Tüm çözümlemeler (analizler) için Sosyal Bilimlerde yaygın olarak kullanılan bir istatistik paket programının 22. sürümünden yararlanılmıştır. Elde edilen bulgular izleyen alt başlıkta detaylı olarak verilmiştir.

Tablo 1.Kat1lımc1ların demografik bilgileri

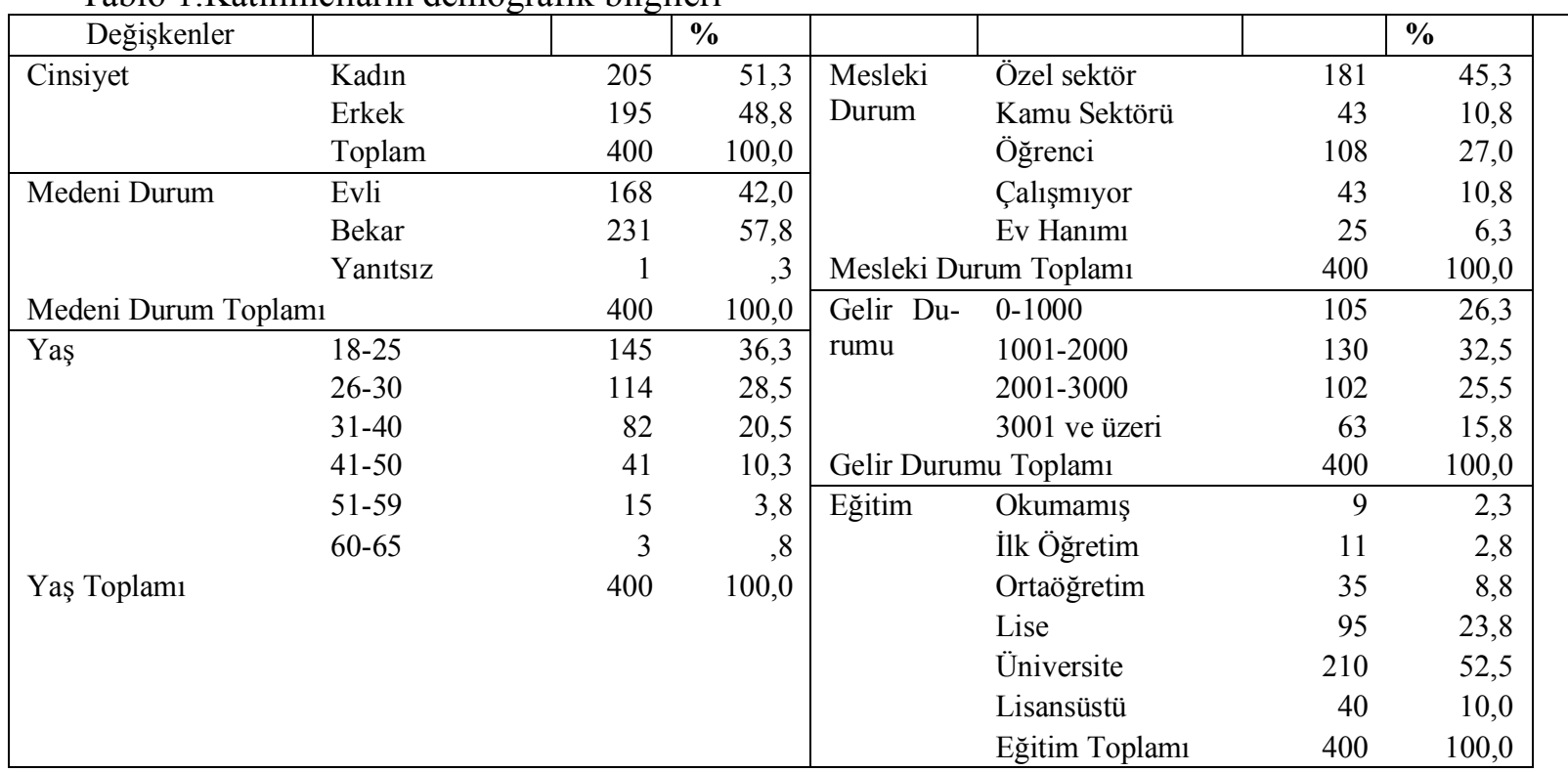




\section{Bulgular}

Araştırmaya gönüllü 400 birey katılmış olup, araştırmaya katılan örneklemle ilgili demografik bulgular Tablo 1'de verilmiştir.

Katılımcılardan 205'i kadın, 195'i ise erkektir. Evli olanların sayısı 168, bekâr olanların sayısı ise 231 olup toplama oranı $\% 57,8^{\prime}$ 'dir. Katılımcıların önemli bir bölümü (yaklaşık \%65'i) 18 ila 30 yaş aralığında olup katılımcıların büyük bir çoğunluğu (yaklaşı \%63'ü) üniversite ve lisansüstü eğitim almış bireylerden oluşmuştur. Katılımciların \%45,3'ü (181) Özel Sektör'de, $\% 10,8$ 'ü (43) Kamu Sektörü’nde çalıştıklarını belirtirken; \%27'sinin (108) Öğrenci, \%6,3'ünün (25) Ev Hanımı olduğu ve $\% 10,8$ 'inin (43) ise herhangi bir yerde çalışmadığı belirlenmiştir. Katılımcıların yarıdan fazlası (yaklaşık \%58) 1001 ila 3.000 TL aralığında aylık gelire sahiptirler.

Keiser Meyer Olkin (KMO) değeri, ankette yer alan ifadelerin Faktör Analizi için uygun olup olmadığını gösteren bir değerdir. KMO değeri olarak 0,5 ve 1 aras1 değerler kabul edilebilir olarak değerlendirilebilir. Fakat genel olarak araştırmacılar asgari KMO değerini 0,7 olarak kabul etmektedirler (Altunışık vd., 2007).

Tablo 2. KMO ve Bartlett's Testi Sonuçları

\begin{tabular}{|c|c|c|}
\hline \multicolumn{2}{|c|}{$\begin{array}{r}\text { Kaiser-Meyer-Olkin } \\
\text { Örneklem Yeterliliği Ölçütü }\end{array}$} &, 944 \\
\hline \multirow{2}{*}{$\begin{array}{c}\text { Bartlett Kür- } \\
\text { sellik Testi }\end{array}$} & Approx. Chi-Square & 5603,380 \\
\cline { 2 - 3 } & $\mathrm{df}$ & 105 \\
\cline { 2 - 3 } & Sig. & 0,000 \\
\hline
\end{tabular}

Tablo 2`de görüldüğü gibi araştırma sonucuna göre ölçeğin Kaiser-Meyer-Olkin (KMO) değeri, sig. $(\mathrm{p})=$ 0,000 anlamlılık düzeyinde 0,944 'dir. Bununla birlikte Bartlett Küresellik Testi sonucu 5603,380 bulunmuştur. Bu değerler Nunnally ve Bernstein (1994)'e göre örneklem büyüklüğü ve elde edilen verilerin Faktör Analizi için yeterli olduğunu göstermektedir (Nunnally ve Bernstein, 1994).

\begin{tabular}{|c|c|c|c|}
\hline Bileşenler ve Faktörler & $\begin{array}{c}\text { Faktör Yük } \\
\text { Değerleri }\end{array}$ & Özdeğer & $\begin{array}{c}\text { Açıklanan } \\
\text { Varyans }\end{array}$ \\
\hline Faktör 1- İşlevsel Kalite & & 4,435 & 29,569 \\
\hline 4- Yiyecek ve içecek personeli cana yakındır & ,837 & & \\
\hline 3- Yiyecek ve içecek personeli güler yüzlüdür & ,831 & & \\
\hline 5- Yiyecek ve içecek personeli yardımseverdir & 801 & & \\
\hline 2- Yiyecek ve içecek personeli hizmet sunumunda yeterlidir & ,747 & & \\
\hline 1-Yiyecek ve içecek personeli hizmet sunumunda isteklidir & ,734 & & \\
\hline 6- Yiyecek ve içecek personeli temizdir &, 624 & & \\
\hline Faktör 2- Teknik Kalite & & 3,770 & 23,137 \\
\hline 9- Yiyeceklerin ve içeceklerin sunum biçimi güzeldir & 815 & & \\
\hline 10- Sunulan yiyecek ve içeceklerin tat ve lezzetleri güzeldir & ,737 & & \\
\hline 8- Sunulan yiyecek ve içeceklerin miktarı uygundur & ,731 & & \\
\hline 7- İşletmenin sunduğu yiyecek ve içecek çeşitliliği yeterlidir & ,562 & & \\
\hline 11- Sunulan yiyecek ve içecekler farklı kültürler yansıtıyor &, 517 & & \\
\hline Faktör 3- İmaj Kalitesi & & 2,546 & 16,975 \\
\hline 13- İşletme görünüm açısından temizdir & ,766 & & \\
\hline 14- İşletmeyi tanıdıklarıma tavsiye ederim & ,638 & & \\
\hline 12- Yiyecek ve içecek hazırlanan alanlar temizdir &, 593 & & \\
\hline 15- İşletmeyi tekrar tercih ederim &, 584 & & \\
\hline
\end{tabular}

Araştırmada katılımcıların doyumlarına etki eden faktörler indirgenmiş boyutlarıyla da ortaya konmuştur. Bu amaçla yapılan Faktör Analizi'nde üç boyut Copyright $(\mathcal{C} 2015$ by JTTR elde edilmiştir. Elde edilen bu üç boyut, her bir boyutu oluşturan değişkenlere göre yeniden adlandırılmıştır. Birinci boyutta bir başka ifadeyle Faktör 1 altında 6 
değişken kümelenmiş ve “İslevsel Kalite Faktörü” olarak adlandırılmıştır. İkinci faktör (boyut) altında kümelenen değişken sayısı ise 5 olup "Teknik Kalite Faktörü” olarak adlandırılmıştır. Üçüncü ve son boyut altında kümelenen değişken sayısı ise 4'tür. Bu boyuta ise "Imaj Kalitesi Faktörü" adı verilmiştir. Bu boyutları oluşturan değişkenler, taşımış oldukları faktör yükleri, özdeğer ve açıkladıkları varyans Tablo 3.'te verilmiştir. Faktör Analizi sonrası elde edilen yeni boyutlara ilişkin güvenirlik analizi de yapılmıştır. Bu analize ilişkin sonuçlar Tablo 4.'te verilmiştir.

Tablo 4. Güvenirlik Analizi Sonuçları

\begin{tabular}{|c|c|c|}
\hline \multicolumn{2}{|c|}{ Cronbach's Alfa Katsayısı } & İfade Sayısı \\
\hline \multicolumn{2}{|c|}{,955 } & 15 \\
\hline \multicolumn{3}{|c|}{ Faktör Analizi Sonrası Güvenirlik Testi Sonuçları } \\
\hline $\begin{array}{c}\text { Faktör 1- İş- } \\
\text { levsel Kalite } \\
\text { Faktörü }\end{array}$ & $\begin{array}{c}\text { Faktör 2- Teknik } \\
\text { Kalite Faktörü }\end{array}$ & $\begin{array}{l}\text { Faktör 3- İmaj Ka- } \\
\text { litesi Faktörü }\end{array}$ \\
\hline ,943 & ,885 & ,926 \\
\hline
\end{tabular}

\section{Tartış̧ma, sonuç ve öneriler}

Hizmetler Sektörü'nün lokomotiflerinden biri olan Yiyecek İçecek Hizmetleri Endüstrisi çağdaş ekonomiler içerisinde gün geçtikte daha önemli bir rol üstlenmektedir. Yoğun ve stresli iş yaşamı, insanların sürekli yaşadıkları yerlerden uzaklaşıp rahatlamaları gereksinimini doğurmuştur. Bu ihtiyaç arttıkça, küresel ekonomi düşünüldüğünde rekabet ortamının da buna paralel olarak daha da çetin bir hal aldığ 1 rahatlıkla söylenebilir. Bu zor rekabet koşullarında hizmet kalitesinin ve tüketici doyumunun başarıyı getirecek iki önemli koşul olduğu ifade edilebilir.

Her sektörde olduğu gibi Yiyecek İçecek Hizmetleri Endüstrisi'nde de yaşanan teknolojik gelişmeler ve tüm dünyada artan eğilim göz önünde bulundurulduğunda, gelecek yıllarda ürün ve/veya hizmet alan kişilerin satın aldıkları ürün ve/veya hizmetin kalitesine ve bundan sağladıkları doyuma daha fazla önem verecekleri öngörülmektedir. Bu çalışmada Kastamonu'da etkinlik gösteren yiyecek içecek işletmelerinde sunulan ürün ve hizmetlerin kalitesinin yanı sıra bu ürün ve hizmetlerden tüketicilerin elde ettikleri doyum ortaya konmak istenmiştir. $\mathrm{Bu}$ amaçların gerçekleştirilebilmesi için öncelikle ilgili yazın (literatür) taranmış ve elde edilen bilgiler yardımıyla bir anket formu geliştirilmiştir. Anket formu 400 gönüllü kişiye uygulanmıştır. Araştırmanın bulgularına göre katılımcıların büyük çoğunluğunun 18 ila 30 yaş arasında olduğu, lisans ve lisansüstü eğitim aldıkları görülmüştür. Ölçekte yer alan ifadelere uygulanan Faktör Analizi sonucunda üç boyutlu bir yapı elde edilmiş ve bu boyutlar İşlevsel Kalite, Teknik Kalite ve İmaj Kalitesi (Faktörleri) olarak adlandırılmıştır. İlk faktörde yer alan "Yiyecek ve içecek personeli cana yakındı" " ifadesi; ikinci faktörde ise "Yiyeceklerin ve içeceklerin sunum biçimi güzeldir", son olarak üçüncü faktörde yer alan "İşletme görünüm açısından temizdir" ifadeleri katılımcıların en fazla önem verdikleri değişkenler olarak belirlenmiştir.

Bilgin (2017) tarafindan yapılan "Restoran İşetmelerinde Hizmet Kalitesi, Müşteri Memnuniyeti ve Müşteri Sadakatinin A ğızdan Ağıza Pazarlamaya Etkisi” adlı çalışmada da benzer sonuçlar elde edilmiştir. " $E t$ kileşim Kalitesi", "Fiziksel Çevre Kalitesi" ve "Çıktı Kalitesi" olmak üzere üç boyutta açıklanan bir kalite olgusunun var olduğu varsayımından hareket edilen çalışmada, sözü edilen bileşenlerin hizmet kalitesini oluşturduğu vurgulanmıştır. Araştırmada ayrıca sözü edilen üç boyutun "Müşteri Memnuniyeti" ve "Müşteri Sadakati" olmak üzere iki önemli sonuç doğurduğu ve bu sonuçların da ağızdan ağıza pazarlamaya yol açtığı sonucuna varılmıştır (Bilgin, 2017).

Bilgin ve Kethüda tarafından Bartın'da yürütülen çalışmada bir restoran işletmesini ziyaret eden müşterilerin hizmet kalitesi algılarının müşteri memnuniyetine ve müşteri sadakatine etkisi DINESERV modeliyle araştırılmıştır. Müşterilerin restoran işletmesinden almış oldukları hizmetlerin kalitesine ilişkin değerlendirmeler DINESERV modeli kullanılarak ölçülmüştür. Analiz sonucunda, DINESERV hizmet kalitesi ölçüm modelinden farklı olarak güven ve empati boyutlarının aynı boyut altında toplandığ 1 ve restoran işletmesinde hizmet kalitesinin dört boyuttan oluştuğu belirlenmiştir. Elde edilen bu dört faktör Güven ve Empati, Fiziksel Olanaklar, Güvenirlik ve Heveslilik olarak adlandırılmıştır.

$\mathrm{Bu}$ çalışmada, daha önce sıkça kullanılan SERVQUAL, DINESERV, DINEPERF gibi ölçekler kullanılmamış olup, Kastamonu örneğinde daha özel bir araştırma yapabilmek gayesiyle özgün bir anket formu geliştirilmiştir. Ayrıca, daha önce yapılan çalışmalarda, genellikle hizmet kalitesinin sadakat üzerindeki etkisi araştırılmış iken Kastamonu'da yapılan bu araştırmada belirgin olarak hizmet kalitesi ve tüketici doyumu ele alınmaya çalışılmıştır. Bunların dışında, 
işletmelerin görünüm bakımından temizliği, yiyecekiçecek personelinin cana yakınlığı ve yiyecek-içeceklerin sunum biçimlerinin güzel oluşu ifadelerinin kat1lımc1lar tarafindan en yüksek öneme sahip olanlar olarak ortaya konulması, araştırmanın diğer bir farkını ortaya koymuştur. Araştırmanın Kastamonu'da bu alanda yapılan ilk çalışma olması araştırmanın bir diğer özgün yanıdır.

Sonuç olarak, araştırma bulguları Kastamonu'da bulunan yiyecek içecek işletmelerini tercih eden tüketicilerin almış oldukları hizmet kalitesinden genel olarak memnun olduklarını ortaya koymuştur. Ancak, gastronomi olgusunun Kastamonu için çok önemli olmas1, Kastamonu'nun son derece zengin bir mutfağa sahip olması ve bu durumun gelecek vadetmesi, hizmet kalitesinin ve tüketici doyumunun daha ilerilere taşınması gerektiği olgusunu doğurmaktadır. Buradan hareketle, her ne kadar Kastamonu' daki yiyecek içecek işletmelerinin ürün ve hizmet kalitesinden genel bir memnuniyet duyulsa da sektöre ve akademiye yönelik;

- Tüketicinin kendisini özel hissetmesi bakımından, her kesimden müşteriye standart bir hizmet sunulmas1,

- Şayet bu olanaklı değil ise, kurum yöneticisi veya dişarıdan gelecek nitelikli kişiler tarafindan işletme içi eğitimlerin verilmesi,

- Tüketicilerin ne tür mal ve hizmete, hangi seviyede ilgi duyduklarının titizlikle tespit edilmesi,

- Hizmet endüstrisindeki uluslararası öncül işletmelerin rol model olarak alınması,

- Yiyecek-içecek endüstrisindeki teknolojik gelişmelerin göz önünde bulundurularak, yöresellikle yoğrulması,

- Kastamonu örneğinin daha kapsamlı bir şekilde tüm bölgeye veya yurda uygulanması önerileri s1ralanabilir.

\section{Kaynakça}

Aksu, M. \& Memiş, H. (2017). Yiyecek ve İçecek İşletmelerinde Hizmet Kalitesinin Dineserv Modeli ile Ölçümü: Çanakkale İli Örneği. Journal of Life Economics, 4(4), 191-206.

Alpar, R. (2017). Uygulamalı Çok Değişkenli İstatistiksel uygulamalar, Beşinci Baskı, Ankara: Detay Yayıncılık.
Altunışık, R., Coşkun, R., Bayraktaroğlu, S., \& Yıldırım, E. (2007). Sosyal bilimlerde araştırma yöntemleri. Sakarya: Sakarya Yayınc1lı. .

Anderson, S. R. \& Saussure, de L. (2018). René de Saussure and the theory of word formation, Anderson, Stephen R. \& Louis de Saussure (Ed., Classics in Linguistics 6), Berlin: Language Science Press.

Apte, U. M., Karmarkar, U. S., \& Pitbladdo, R. (1997). Quality management in services: Analysis and measurement, Southern Methodist University Historical Working Papers Cox School of Business, 94-0901,Boston MA. Springer.

Arıker, C. (2012). Tüketicilerin restoran seçiminde kullandıkları seçim kriterleri ile demografik özellikleri arasındaki ilişki, Öneri, 10(389), 11-31.

Arslan, S. (2015). Turizm Seferberliği, KATSO Dergi, Kastamonu Ticaret ve Sanayi Odası, Ocak-Mart.

ASQ. (2019). Quality Glossary, Erişim tarihi 24 Ocak 2019, https://asq.org/quality-resources/quality-glossary/q

Ayaz, N. \& Yal, S. (2017). Kültürel Turistlerin Seyahat Tercihleri ve Yiyecek-İçecek Beklentileri: Safranbolu örneği, Türk Turizm Araştırmaları Dergisi, 1(1), 43-61.

Aydoğdu, A., \& Duman, S. (2017). Destinasyon Çekicilik Unsuru Olarak Gastronomi Turizmi: Kastamonu Örneği. Turar Turizm \& Araştırma Dergisi, 6(1), 4-23.

Aydoğdu, A., Pamukçu, H., \& Yaşarsoy, E. (2015). Konaklama İşletmelerinin Engelli Bireylere Uygunluğu: Kastamonu Örneği, III. Rekreasyon Araştırmaları Kongresi, 5-7 Kasım, Eskişehir, 358-368.

Aytar, O., Çil, U., Hoşbay Bayraktar, D., \& Soylu, Ş. (2018). Hizmet Kalitesi Ölçüm Yöntemleri ve Yükseköğretimde Stratejik Yönetim Bilgi Kaynağı Yöntem Önerisi. Journal of Higher Education \& Science/Yüksekögretim ve Bilim Dergisi, 8(2), 245-253.

Babaş, T. (2014). Kastamonu Turizminin Bir Master Planı Olmalı, Doğru Eksen Haber ve Ekonomi Dergisi, 3(17), 21-24.

Balaban, Ö. \& Özdemir, Y. (2013). Kadın Girişimcilerin İş Yaşam Dengesi Algısının Belirlenmesine Yönelik Bir Araştırma: Sakarya Örneği. Erdoğan Kaygın ve Bülent Güven (Ed.), Farklı Boyutlarıyla Kadın Girişimcilik içinde (s. 113-137). İstanbul: Veritas Akademi.

Başöz, B. (2017). Kadınların sosyal ve ekonomik hayata katılımında hanımlar lokali (Konya örneği). (Yayınlanmamış Yüksek Lisans Tezi). Selçuk Üniversitesi/Sosyal Bilimler Enstitüsü, Konya. 
Bilgin, Y. (2017). Restoran İşletmelerinde Hizmet Kalitesi, Müşteri Memnuniyeti ve Müşteri Sadakatinin Ağızdan Ağıza Pazarlamaya Etkisi, İsletme Araştırmaları Dergisi, 9(4), 33-62.

Bilgin, Y., \& Kethüda, Ö. (2017). Restoran İşletmelerinde Hizmet Kalitesinin Müşteri Memnuniyetine ve Sadakatine Etkisi: Oba Restoran Örneği. Çankırı Karatekin Üniversitesi IIBFF Dergisi, 7(2), 147-170.

Bucak, T. \& Turan, Ö. (2016). Restoranlarda Hizmet Kalitesinin Misafir Memnuniyetine Etkisi: Çanakkale Merkezinde Bir Araştırma. Journal of Academic Social Science Studies, (49), 287-304.

Buckley, P. ve Majimdar, R. (2018). The services powerhouse: Increasingly vital to world economic growth, Erişim tarihi, 24 Ocak 2019, https://www2.deloitte.com/insights/us/en/economy/issues-by-the-numbers/trade-inservices-economy-growth.html.

Büyüköztürk, Ş. (2002). Faktör analizi: Temel kavramlar ve ölçek geliştirmede kullanımı. Kuram ve Uygulamada Eğitim Yönetimi, 32 (32), 470-483.

Brandday. (2018). Türkiye'de Yeme-İ̧̧me Sektörünün Boyutlarl Gastronomi Ekonomisi Ara Rapor 2018, Erişim tarihi: 20 Ocak 2019, http://www.brandday.net/ekonomi/turkiyede-yeme-icme-sektorunun-boyutlari-gastronomi-ekonomisi-ara-rapor-2018-h8213.html

Bekar, A. \& Kılıç, B. (2015). Hizmet Kalitesi Memnuniyet İlişkisi: Üniversite Kampüsünde Faaliyet Gösteren Yiyecek İçecek İşletmelerinde Karşılaştırılmalı Bir Uygulama. Sosyal ve Beşeri Bilimler Araştırmaları Dergisi, (34), 1-24

Chen, Y. H., He, Q. \& Paudel, K. P. (2018). Quality competition and reputation of restaurants: the effects of capacity constraints, Economic research-Ekonomska istraživanja, 31(1), 102-118

Collier, D. A. (1990). Measuring and managing service quality. Service Management Effectiveness San Francisco, CA: Jossey-Bass.

Crawford, E. (2016). The eight factors that could predict "the next big thing" in the food and beverage industry, Erişim tarihi: 19 Ocak 2019, https://www.bakeryandsnacks.com/Article/2015/03/10/8-factors-to-predict-thenext-big-thing-in-the-food-beverage-industry.

Cronin, J. J. \& Taylor, A. S. (1992). Measuring Service Quality: A Reexamination and Extension. Journal of Marketing, 56(July), 55-67.
Cronin Jr, J. J., Brady, M. K., \& Hult, G. T. M. (2000). Assessing the effects of quality, value, and customer satisfaction on consumer behavioral intentions in service environments. Journal of retailing, 76(2), 193-218.

Crosby, L. A., Evans, K. R., \& Cowles, D. (1990). Relationship quality in services selling: an interpersonal influence perspective. The journal of marketing, 68-81.

Dalgıç, A. (2013). Hizmet Sektöründe Hizmet Kalitesinin Ölçümü ve Hizmet Kalitesini Etkileyen Faktörler: Antalya'da Hizmet Kalitesi Ölçümüne Yönelik Bir Uygulama. (Yayınlanmamış Yüksek Lisans Tezi). Adnan Menderes Üniversitesi/Sosyal Bilimler Enstitüsü, Aydın.

De Silva, D., Elliott, C., \& Simmons, R. (2013). Restaurant wars: spatial competition in UK restaurants., Economics Working Paper Series 2013/013, Department of Economics Lancaster University Management School, Lancaster.

Denizer, D. (2005). Konaklama İşletmelerinde Yiyecek ve İçecek Yönetimi. Ankara: Detay Yayıncılık.

Duman, T. (2003). Richard L. Oliver'in Tüketici Memnuniyeti (Consumer Satisfaction) ve Tüketici Değer Algisı (Consumer Value) Kavramları Hakkındaki Görüşleri: Teorik Bir Karşılaştırma, Dokuz Eylül Üniversitesi, Sosyal Bilimler Enstitüsü Dergisi, 3(2), 45-56.

Duman, T. \& Öztürk, A. B. (2005). Yerli Turistlerin Mersin Kızkalesi Destinasyonu ve Tekrar Ziyaret Niyetleri ile İlgili Algılamaları Üzerine Bir Araştırma. Anatolia: Turizm Araştırmaları Dergisi, 16(1), Bahar, 9-23.

Ekmekçi, R., \& Ekmekçi, A. Y. (2010). Sport marketing. Pamukkale Journal of Sport Sciences, 1(1), 23-30.

Eleren, A. (2009). Müşteri Beklentilerine Dayalı Bir Hizmet Kalitesi Ölçüm Modeli: Termal Otel İşletmeciliğinde Bir Uygulama. Sosyal ve Ekonomik Araşttrmalar Dergisi, 18, 395-420.

Ersöz, S., Pınarbaşı, M., Türker, A. K., \& Yüzükırmızı, M. (2009). Hizmet Kalitesinin Servqual Metodu İle Ölçümü ve Sonuçların Yapısal Eşitlik Modelleri ile Analizi: Öğretmen Evi Uygulaması. Uluslararast Mühendislik Araştırma ve Geliştirme Dergisi, 1(1), 19-27

Filiz, Z. \& Kolukısaoğlu, S. (2013). Servqual Yöntemi ve Bir Hizmet İşletmesinde Uygulaması. I, Dumlupınar Üniversitesi Sosyal Bilimler Dergisi, EYİ Özel Sayıs1, 253-266.

Fox, M. J. (2013). Quality assurance management. Berlin: Springer.

Köktaş, A. M. \& Gölçek, A. G. (2016). Endüstri Devrimi ve Osmanlı İmparatorluğu: Askeri Fabrikalaşma Örneği. Ömer Halisdemir Üniversitesi İktisadi ve İdari Bilimler Fakültesi Dergisi, 9(4), 95-105. 
Ghotbabadi, A. R., Feiz, S., \& Baharun, R. (2015). Service quality measurements: a review. International Journal of Academic Research in Business and Social Sciences, 5(2), 267.

Grönroos, C. (1983). Innovative marketing strategies and organization structures for service firms. Emerging perspectives on services marketing, 9-21.

Grönroos, C. (1990). Service management and marketing: Managing the moments of truth in service competition. San Francisco, CA: Jossey-Bass.

Guthrie, J. F., Lin, B. H., \& Frazao, E. (2002). Role of food prepared away from home in the American diet, 1977-78 versus 1994-96: changes and consequences, Journal of nutrition education and behavior, 34(3), 140-150.

Halis, M., Türkay, O. \& Akova, O. (2010). Turizm Sektörü İçin Toplam Kalite Yönetimi. Şehnaz Demirkol ve Muhsin Halis (Ed.), Turizm Issletmelerinde Toplam Kalite Yönetimi içinde (s. 37-108), Sakarya: Değişim Yayınlar1.

Hotelrestoranmagazin. (2018). TAVAK, “Türkiye'de Gastronomi Ekonomisi Araştırması"nı yayınladı, Erişim tarihi: 20 Ocak 2019, http://www.hotelrestaurantmagazine.com/tavak-turkiyede-gastronomi-ekonomisi-arastirmasini-yayinladi/

ILO. (2018). World Employment and Social Outlook: Trends for Women 2018 - Global snapshot, Geneva.

İpekgil-Doğan, Ö. \& Tütüncü, Ö. (2003). Hizmet İşletmelerinde Toplam Kalite Yönetimi Kapsamında ISO 9001: 2000 ve Bilgisayar Destekli Bir Uygulama. İzmir: Dokuz Eylül Üniversitesi Rektörlüğü Yayınları.

Juran, J. M. (1995). A history of managing for quality: The evolution, trends, and future directions of managing for quality. Milwaukee: ASQC Quality press.

Karasar, N. (1984). Bilimsel araştırma metodu. Ankara: Hacetepe Taş Kitapçılık.

Kaya, C. (2009). Çalışma Yaşamında Kadın İşgücü Sorunları ve Örgütlenme Eğilimleri. (Yayınlanmamış Doktora Tezi). Dokuz Eylül Üniversitesi/Sosyal Bilimler Enstitüsü, İzmir.

King, L. W. (2015). The Code of Hammurabi, New York: Create Space Independent Publishing Platform.

Koçbek, A. D. (2005). Yiyecek İçecek Sektöründe Hizmet Kalitesi ve Müşteri Memnuniyeti: Etnik Restoranlara Yönelik Bir Araştırma. (Yayınlanmamış Yüksek Lisans Tezi). Anadolu Üniversitesi/Sosyal Bilimler Enstitüsü, Eskişehir.
Krejcie, R. V.,\& Morgan, D. W. (1970). Determining sample size for research activities, Educational and psychological measurement, 30(3), 607-610.

Kumar, S. \& Bhatnagar, D. (2017). Effect of Food and Service Quality on Customer Satisfaction a Study of 3 Star Hotels in Punjab Region. International Journal of Sales \& Marketing Management Research and Development, 7(4), 35-48

Kuzu, A. (2010). Yaşlı Bakım Kurumlarında Hizmet Kalitesi Kavramı ve Kavramsal Hizmet Kalitesi Modeli: SERVQUAL Uygulaması. (Yayımlanmamış doktora tezi). Sakarya Üniversitesi/Sosyal Bilimler Enstitüsü, Sakarya.

Lehtinen, J. R. (1983). Customer oriented service system. Service Management Institute, Finland, Helsinki.

Lennon, C. (2008). Trade in services and trade in goods: differences and complementarities. PSE Working Papers $n^{\circ} 2008-52$.

Lewis, R. C., \& Bernard, H. Booms (1983). The Marketing Aspects of Service Quality. L. Berry, L. Shostack, and G. Upah (Ed.), In Emerging Perspectives on Services Marketing, (pp. 99-107), Chicago: American Marketing Association.

Liu, Y., Yu, Y., Wang, K., Boles, C. D., November-Rider, D., Yadav, R. \& Collins, C. (2016). Frequency of NotHome Prepared Meals and Diet Quality are Associated with Depression and Metabolic Syndrome Among US Adults. Diabetes Obes Int, 1(7), 1-11.

Majabadi, H. A., Solhi, M., Montazeri, A., Shojaeizadeh, D., Nejat, S., Farahani, F. K., \& Djazayeri, A. (2016). Factors influencing fast-food consumption among adolescents in tehran: a qualitative study. Iranian Red Crescent Medical Journal, 18(3).

Marković, S., Komsic, J. \& Stifanic, M. (2013). Measuring service quality in city restaurant settings using DINESERV scale. Recent Advances in Business Management and Marketing, 176-181.

Marković, S., Raspor, S., \& Šegarić, K. (2010). Does restaurant performance meet customers' expectations? An assessment of restaurant service quality using a modified DINESERV approach, Tourism and Hospitality Management, 16(2), 181-195.

Mensah, I. (2009). Customers' perception of food service quality: the case of Cape Coast. Journal of business and enterprise development, 1(1), 138-154.

Ming, W., \& Sheih, C. J. (2006). The Relationship Between Service Quality and Satisfaction. Journal of Information and Optimization Sciences, 27(1), 193-209. 
Nunnally, J.C. \& Bernstein, I.H. (1994). Psychometric Theory, 3rd. Edn, New York: Mcgraw-Hill.

Oğlakcıoğlu, Z. (2013). Butik Otellerde Müşteri Memnuniyeti ve Hizmet Kalitesi İlişkileri: İzmir Örneği. (Yayınlanmamış Yüksek Lisans Tezi). Dokuz Eylül Üniversitesi/Sosyal Bilimler Enstitüsü, İzmir.

Oh, H. (1999). Service quality, customer satisfaction, and customer value: A holistic perspective, International Journal of Hospitality Management, 18(1), 67-82.

Olcay, A., \& Özekici, Y. K. (2015). Yiyecek-İçecek İşletmelerinde Hizmet Hataları, Telafi Yöntemleri ve Müşteri Memnuniyeti İlişkisi (Gaziantep Örneği). Uluslararası Sosyal Araştırmalar Dergisi, 41(8), 1254-1268.

Oliver, R. L. (1997). Satisfaction: A behavioral perspective on customer. Boston, MA: Irwin, McGraw-Hill.

Orfanos, P., Naska, A., Trichopoulos, D., Slimani, N., Ferrari, P., van Bakel, M., ... \& de Magistris, M. S. (2007). Eating out of home and its correlates in 10 European countries. The European Prospective Investigation into Cancer and Nutrition (EPIC) study. Public health nutrition, 10(12), 1515-1525.

Özdemir, B. (2010). Dışarıda Yemek Yeme Olgusu: Kuramsal Bir Model Önerisi. Anatolia: Turizm Araştırmaları Dergisi, 21(2), 218-232.

Özer, A. (2015). Frederıck Taylor’ın Görüşlerini 21. Yüzyıl Yönetim Mantığı İle Yeniden Okumak. Verimlilik Dergisi, (2), 41-72.

Parasuraman, A., Zeithaml, V. A., \& Berry, L. L. (1985). A conceptual model of service quality and its implications for future research. The Journal of Marketing, 41-50.

Parasuraman, A., Berry, L. L., \& Zeithaml, V. A. (1990). Guidelines for Conducting Service Quality Research. Marketing Research, 2(4), 34-44.

Parasuraman, A., Berry, L. L., \& Zeithaml, V. A. (1991). Understanding customer expectations of service. Sloan management review, 32(3), 39-48.

Parasuraman, A., Zeithaml, V. A., \& Berry, L. L. (1994). Reassessment of expectations as a comparison standard in measuring service quality: implications for further research. the Journal of Marketing, 111-124.

Rao, P. S., \& Sahu, P. C. (2013). Impact of service quality on customer satisfaction in hotel industry. IOSR Journal of Humanities and Social Science, 18(5), 39-44.

Rewardsnetwork. (2017). 2018 Restaurant Trends: Industry, Erişim tarihi: 20 Ocak 2019, https:/www.rewardsnetwork.com/blog/2018-restaurant-trends-industry/
Robson, S. M., Crosby, L. E., \& Stark, L. J. (2016). Eating dinner away from home: perspectives of middle-to highincome parents. Appetite, 96, 147-153.

Sandholm, Y. \& Kondo, Y. (1999). Juran, Quality, and a Century of Improvement. Kenneth S. Stephens (Ed.), In The Global Influence (pp. 65-82), ASQ, Milwaukee: Quality Press.

Sasser, W. E., Olsen, R. P., \& Wyckoff, D. D. (1978). Management of service operations: Text, cases, and readings. Boston, MA: Allyn \& Bacon.

Songur, L., Turan, A. ve Songur, G. (2017). Sağlik Sektöründe Hizmet Kalitesinin Servperf Ölçeği İle Ölçülmesi:" Şereflikoçhisar Devlet Hastanesi Örneği". Journal Of International Social Research, 10(53), 807-819.

STATISTA. (2019a). Food and Beverages Worldwide, Erişim tarihi: 20 Ocak 2019, https:/www.statista.com/statistics/244616/number-of-qsr-fsr-chain-independentrestaurants-in-the-us/

STATISTA. (2019b). Restaurants and food services in Europe - Statistics \& Facts, Erişim tarihi: 20 Ocak 2019, https:/www.statista.com/statistics/684198/number-ofenterprises-in-the-food-and-beverage-service-industryin-the-eu/

Stevens, P., Knutson, B. \& Patton, M. (1995). DINESERV: A Tool for Measuring Service Quality in Restaurants, The Cornell Hotel and Restaurant Administration Quarterly, 36(2), 56-60.

Süren, T. \& Küçükkömürler, S. (2018). Ev dış1 et tüketimi. Journal of Tourism and Gastronomy Studies, 6(3), 3952.

Tanilli, S. (2002). Dünyayı Değiştiren 10 Yıl: Fransız Devrimi üstüne (1789-1799). İstanbul: Adam Yayınları.

Tavmergen, İ. P. (2002). Turizm Sektöründe Kalite Yönetimi. Ankara: Seçkin Yayıncılık.

Tran, T. P. D. (2018). Service quality in Food \& Beverage business in Metropolitan area. (Yayınlanmamıs Yüksek Lisans Tezi). Haaga Helia University/Applied Sciences, Helsinki.

Tuncer, İ. (2017). Yiyecek İçecek İşletmelerinde Hizmet Kalitesi Boyutları ve Ölçeklerinin İncelenmesi, International Journal of Academic Value Studies, 3(16), 321329.

Tütüncü, Ö. (2001). Yiyecek içecek işletmelerinde müşteri tatmininin ölçülmesi. Ankara: Turhan Kitabevi.

Uyguç, N. (1998). Hizmet sektöründe kalite yönetimi: Stratejik bir yaklaşım. İzmir: Dokuz Eylül Yayınları. 
Yıldırım, C. (1966). Eğitimde Araştırma Metotları. Ankara: Akyıldız Matbaası.

Yılmaz, İ. (2007). Otel İşletmelerinde Hizmet Kalitesinin Müşteriler ve Yöneticiler Açısından Ölçülmesi: İzmir Örneği. (Yayınlanmamış Doktora Tezi). Dokuz Eylül Üniversitesi/Sosyal Bilimler Enstitüsü, İzmir.

Yuen, E. F. T., \& Chan, S. S. L. (2010). The effect of retail service quality and product quality on customer loyalty. Database Marketing \& Customer Strategy Management, $17(3 / 4), 222-240$.

Zeithaml, V. A., Parasuraman, A., \& Berry, L. L. (1985). Problems and strategies in services marketing. The Journal of Marketing, 33-46.

Zeithaml, V. A., Berry, L. L., \& Parasuraman, A. (1996). The behavioral consequences of service quality. Journal of Marketing, 60(2), 31-46.

Zhao, X., Bai, C., \& Hui, Y. V. (2002). An empirical assessment and application of SERVQUAL in a mainland Chinese department store. Total Quality Management, 13(2), 241-254.

\section{Extended abstract in English}

Introduction: Today's societies have begun to consume more of the products and services produced by the food sector, which has reached enormous size. This situation is an outcome of dining out behaviour of contemporary consumers. The fact of dining out is mainly related to the out-of-home food and beverage consumption. From a commercial point of view, dining out is defined as the consumption of food and beverages produced by a food and beverage company outside of peoples' home for a certain fee. Thus, dining out is defined as the starting point of the demand for the products and services produced by the food and beverage businesses. The enterprises providing services in the tourism industry must follow the developments in both technological and social sense in order to meet the needs of customers, to satisfy their customers and to provide quality services. In the light of the narrative, the answers to the following questions were sought in this research:

* What is the service quality of the food and beverage companies in Kastamonu?

* What is the level of satisfaction of the consumers visiting food and beverage companies in Kastamonu?
* What are the factors affecting consumer satisfaction?

Method: The aim of this study was to measure the satisfaction of the consumers as a result of the quality of service offered in the food and beverage establishments in Kastamonu. The research was designed to solve two problems associated with each other. First of all, the quality of service offered by the food and beverage companies in Kastamonu and then, the satisfaction of the consumers were asked to be measured and these issues constituted the scope of the research.

A correlational survey method was used in this study. Consumers who have visited food-beverage establishments in Kastamonu constituted the universe of the study while 400 of them formed the sample of the research. Limitations of the research; both physical and socio-cultural differences in upper, middle and lower forms were determined as the limitations of the study. Specific age range and only Turkish speaking individuals were included in the study. Although children represent an important part in dining out consumption, they were not included in the research.

Face to face and drop-collect questionnaire techniques were implemented in the research. The data were analysed by a statistical package program which is widely used for social sciences. The data obtained from the survey technique were analyzed according to their characteristics. The categorical variables prepared to obtain the demographic information of the participants were analyzed with frequencies and percentages. Expression of independent variables prepared according to the five-point Likert scale for determining satisfaction was analyzed with the factor analysis.

Findings: According to findings of the research, 195 of participants were male while 205 were female. The number of married people were 168 while the number of single people were 231 and the collection rate of singles were $57,8 \%$. A significant proportion of the participants (approximately 65\%) were between 18 and 30 years of age and the majority of the participants (approximately 63\%) had bachelor and graduate degrees. It was also found that 45,3\% (181) of participants were employed by private sector while $10,8 \%$ (43) of them by the public sector. In addition, $27 \%$ (108) of participants were students, $6,3 \%$ (25) of them were housewife and $10,8 \%$ (43) were not employed at 
all. More than half of the participants (approximately 58\%) have 1001-3000 Turkish Liras income.

The factors affecting the satisfaction of the participants in the research were also revealed with their reduced dimensions. Three sub-dimensions were obtained for the factor analysis. The three dimensions were renamed according to the variables forming each dimension. In the first dimension, i.e. under Factor 1, 6 variables were clustered and named Functional Quality Factor. The numbers of variables clustered under the second factor (size) were 5 and named as Technical Quality Dimension. The numbers of variables clustered under the third and last dimension were 4 . This dimension was named as Image Quality Factor. The variables that form these dimensions, the factor loads they carry, the eigenvalue and the variance they explained were given in Table 3. Reliability analysis for new dimensions obtained after factor analysis was also performed. The results of this analysis were given in Table 4.

Discussion and Results: The tourism industry, which is one of the locomotives of the service sector, plays a more important role in the day. Intensive and stressful work life has created the need for people to move away from the places where they live. As this need increases, considering the global economy, it can easily be said that the competitive environment becomes more difficult. Under these difficult competition conditions, it is clear that service quality and consumer satisfaction are the key points that will bring success.

Considering the technological developments in the tourism industry as well as in every sector and the increasing level of education all over the world, it is foreseen that the people receiving the products and / or services in the coming years will place more importance to the quality of the products and / or services they purchase and the satisfaction they will have. In this study, it was aimed to determine the quality of the productservice offered in the food and beverage enterprises operating in Kastamonu and the satisfaction of the consumers from these offered products-services.

'Food and beverage staff is friendly' was determined as the most important variable in the first factor while 'The presentation of food and beverage is nice' was the most important one for the second factor. Lastly, 'The restaurant appears to be clean' was determined as the most crucial statement for the third factor.

Keywords: Food \& Beverage Establishments, Service Quality, Consumer Satisfaction, Kastamonu. 